\title{
Review on rain induced fruit cracking of sweet cherries (Prunus avium L.), its causes and the possibilities of prevention
}

\author{
Simon, G. \\ Horticultural Science Faculty, Department of Fruit Science, \\ Corvinus University of Budapest, Villányi út. 29-43.
}

\begin{abstract}
Summary: The rain induced fruit cracking is a big, serious and costly problem for cherry growers. Cracked fruits lose their value and they are not marketable because of the poor fruit quality. Cracked fruits have different storage diseases and shorter storage and shelf life.

There are many influencing factors of the cherry fruit cracking such as: water uptake; fruit characteristics (fruit size, fruit firmness; anatomy and strength of the fruit skin, stomata in fruit skin, cuticular properties, osmotic concentration, water capacity of the fruit pulp, growth stage of the fruit,); orchard temperature and other environmental conditions;

The most effective protection technique is the plastic rain cover over the tree rows. The installation of these equipments is too expensive for the cherry growers. That is the reason why researchers tried to find other less expensive and sufficiently effective ways against the ran induced fruit cracking.

Several calcium formulas: calcium chloride $\left(\mathrm{CaCl}_{2}\right)$, calcium hydroxide $\left(\mathrm{Ca}(\mathrm{OH})_{2}\right)$ and calcium nitrate $\left(\mathrm{Ca}\left(\mathrm{NO}_{3}\right)_{2}\right)$ can be sprayed in appropriate concentration. Spraying with other mineral salts (aluminium and copper salts, borax) and PBRs (Plant Bioregulators) may be also effective to reduce fruit cracking.
\end{abstract}

Key words: cherry, fruit cracking, fruit quality, rain protection

\section{Introduction}

Rainfall and high humidity during the growing season, particularly at blooming or harvesting time, are serious limitations for profitable sweet cherry production due to fungal diseases which kill the flowers and shoots, or rot the fruits. There is a general opinion that sour cherries are less prone to cracking. Rainfall during harvest is especially harmful, being conditions favoring fruit cracking. In some years with some susceptible sweet cherry cultivars, the ratio of cracked fruits can reach 90\% (Christensen, 1996). These cracked cherry fruits lose their value for fresh market and they are used for processing only (especially for fruit juice) if they are not infected by fungus. Brown rot is extremely bad on cherries, and is worsened by high humidity and rainfall near harvest. Conditions favoring infection of brown rot of sweet cherries caused by Monilinia fructigena and/or $M$. laxa: any type of injury will provide a point of entry for the fungi including hail damage, insect feeding wounds, bird pecks, fruit cracking, limb rubs, twig punctures, picking/packing injuries (Holb, 2003; Holb \& Veisz, 2005).

For these reasons, most sweet cherries are grown in dry climates. In many countries (Germany, Norway, Canada, some state of USA /Washington, Michigan, New York/ etc.) sweet cherry growers try to protect their cherry orchards against fruit cracking damage caused by too much rain.
Although many studies have dealt with this complex phenomenon, the basic mechanisms involved in fruit cracking remained unclear.

The causes of fruit cracking

There are many factors causing fruit cracking (Simon, 2003):

- genetically determined susceptibility of grown species and cultivars (there is a generally accepted opinion that hard fleshed sweet cherry cultivars are more susceptible to cracking than soft fleshed ones);

- the quantity (volume) of rainfall at one time;

- the full quantity and distribution of rainfall during the ripening season of cherries;

- the soil type and soil moisture condition of the cherry orchard.

\section{Water uptake:}

The earliest reports in the literature inform us that cherry fruit racking was thought to be due to excessive water uptake through the root system or the fruit skins. Subsequent research showed that may be only water absorption through the fruit skin leads to fruit cracking (Sawada, 1931; Verner \& Bodget, 1931; Christensen, 1976). 
Properties of cracking on the fruit:

There are three different and well-defined types of cherry fruit cracking (Figure 1):

- circular or semicircular cracks around the stem end in the cavity;

- similar fine crack at the apical end of fruits;

- and many often deep cracks on the side of fruits and it is called as lateral cracking.

The small, fine cracks at the base and apical end of cherry fruit may occur at very early stage, many days before fruit maturity and harvest. These fine cracks at an early stage of fruit development (usually cork over and seal before the fruit ripens) decrease the market value of fruits. In contrast the large, deep, side cracks provide a point of entry for the fungus (brown rot and grey mould) and are frequently followed by severe attacks. After the serious fungus infection, the texture and quality of fruits will be destroyed and become unmarketable.

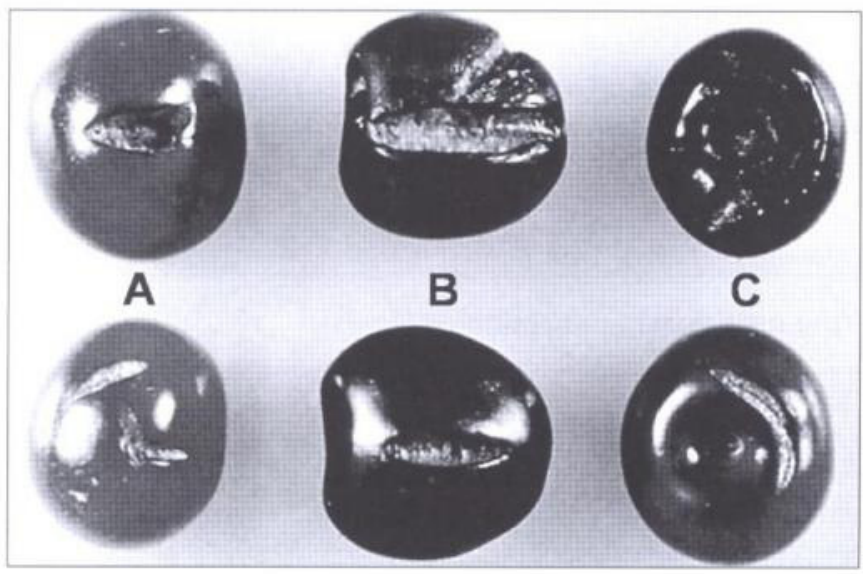

Figure 1 Different type of cherry fruit cracking (A: apical end cracking; B: deep side cracking; C: stem end cracking) (Picture was modified from APS Digital Image Collection

Verner (1937) found that cherries are most often cracked first at apex. Andrsen (2002 personal communication) had the same experience under New York State conditions and he called this type of cracking as "nose cracking". Verner (1937) found that there is a sugar concentration gradient from the stem to the apex. His conclusion was that the higher osmotic concentration of the fruit juice at the apical end accounted for more rapid water absorption of the rain drops through the fruit skin resulting in earlier cracks at this part of the fruit. Later, he also noted that the drop of water usually adhered to the apex of the cherry fruit and in this way the apical end of the fruit has a longer period for potential water absorption.

Uriu et al. (1962) published a study on another stone fruit crop (plum) and they found that lateral splitting and apical cracking are independent phenomena, as irrigation affected the two cracking processes differently. The stage of maturity had the major influence on the development of lateral splits, whereas apical splits appeared immediately after irrigation in areas with a severe water deficit, regardless of the degree of ripeness. Chistensen (1972a) found after a study with 32 sweet cherry cultivars on fruit cracking that there was no correlation between apical cracks and cultivar susceptibility to serious lateral or flesh cracking.

Sawada (1934) found that the fruit shape is also very important factor of fruit cracking. He thought that fruits can crack more easily when they have right angle to the curvature of the shape. He noted that other fruits (grapes, plums) and vegetables (tomato, cabbage and carrots) were affected in a very similar way. According to the author's opinion, the shape of the fruit can play an important role of cherry fruit cracking. Cultivars with kidney or heart fruit shape have deeper stem cavity and the rain drops can stay there for longer time giving possibility for more water absorption through the skin. It means that if a variety is genetically determined (based on structure and thickness of the cuticule and sugar content) for moderate susceptibility to splitting and it has kidney, blocky or heart shape, maybe it will have stem end type splitting. It is in agreement with the findings of Belmans et al. (1989) who found that 'Hedelfinger' cherry fruits cracked at the stem end only.

\section{Factors influencing the fruit cracking}

\section{Fruit characteristics:}

Fruit size: It is generally supposed that large fruit of cherries are more prone to cracking than smaller ones. Several studies (Tucker, 1934; Sekse, 1987) have shown that large fruited cultivars have greater tendency to crack than small-fruited ones. In contrast other studies, comparing more cultivars (Zelinski, 1964; Christensen, 1975) found no relationship between cracking susceptibility and varietaldetermined fruit size. Studies of Bullock (1952) and Way (1967) showed that fruits of heavy crop loaded trees crack less than light cropping trees in the case of the same variety.

Fruit firmness: It is a generally accepted opinion that firmfleshed cherry cultivars have greater tendency to fruit cracking than soft-fleshed ones. Cracking of cherry fruits is caused by excess uptake of water resulting in bursting of the skin, it seems logical that firm-fleshed cultivars are more susceptible to cracking than soft-fleshed ones (Christensen, 1996).

Anatomy and strength of the fruit skin: Studies of Kertesz $\&$ Nebel (1935) showed no relationship between the size of the epidermal cells and the cracking susceptibility, but positive correlation between the thickness of the inner wall of the epidermis and the cracking susceptibility.

Stomata in the fruit skin: Plant physiologist often demonstrated that water absorption in leaves happens mostly through epidermal cells and the absorption through stomata is significant. Sawada (1931) found that at least a part of the water absorbed into cherry fruit comes through the stomata. The density of stomata did not appear to have any significant influence on the amount of water taken up before cracking occurred (Christensen, 1972b). 
Cuticular properties: Glenn \& Poovaiah (1989) noted that water uptake through the fruit skin caused separation of the cuticle from the cell wall and the associated swelling in the epidermal cell wall region resulted in cuticular fracturing, which generally preceded fruit cracking. Belmans et al. (1990) found a very strong correlation between thickness of cuticule and the resistance of 13 varieties. Bangerth (1968) could not find consistent correlation between the fruit cracking susceptibility and the amount or composition of the cuticle.

Osmotic concentration: After early studies in the USA Verner \& Blodgett (1931) had a conclusion that fruit cracking was directly affected by the osmotic concentration of the fruit juice. In contrast Tucker (1934) showed a correlation between the sugar content and cracking tendency of cultivars. He concluded that while sugar content could be of some importance, other varietal factors influenced the cracking tendency to a greater extent.

Water-retaining capacity of the fruit pulp: Kertesz \& Nebel (1935) found that the water-retention capacity and swelling of this colloidal pulp are important in determining cracking susceptibility. Christensen (1972b) had studied 32 sweet and 3 sour cherry varieties and he found no relationship between the retention force and the varietal cracking index. By Christensen's opinion the methods which were used by Kertesz \& Nebel are scientifically unsound, and that is the reason why they obtained a different result.

Correlation between fruit cracking and the stage of fruit development: The generally accepted opinion is that most cultivars show an increasing susceptibility to cracking with advancing maturity, but there are cases of deviation from this relationship. The reason of this deviation is due to climatic conditions influencing the fruit's sensitivity to cracking before the beginning of fruit sampling or picking (Christensen, 1996).

\section{Environmental influences on fruit cracking of cherries:}

Influence of temperature: Several researchers showed that temperature plays a very important role in the rate of fruit cracking. In general, there was a linear increase in cracking with temperature increase from 10 to $40^{\circ} \mathrm{C}$. Of course, the temperature also affects many other factors such as permeability of the cell walls and biochemical processes of the cells etc. It is very important to know the influence of temperature in fruit cracking if we want to find some measure against fruit cracking, because usually the temperature is higher underneath the screen than outside.

\section{Possibilities of prevention}

Researchers agree that the appropriate site selection is the most effective way to minimize the rain damage of cherry orchards. The appropriate site should be with little or no rain incidence at or near harvest time. Unfortunately, this is only an option in few cherry producer countries such as Norway, Canada, USA and Switzerland. In these countries - with rainy climate conditions in cherry harvest time - trials were started to find other solutions. Other alternatives are:

- to choose cultivars which show some resistance to rain induced fruit cracking;

- physically protecting sweet cherry fruits by water resistant covers from rain damage.

- or to spray the fruits with minerals, surfactants or plant growth regulators to improve their natural resistance to rain damage;

\section{The choice of cultivars:}

To get objective data on the cracking tendency of sweet cherry cultivars is quite difficult because there are different opinions about the same variety according to authors, location of cherry orchard and the climate conditions especially considering the rainfall. In Table 1 , there are collected data with fruit parameters (fruit size, fruit shape, firmness of fruit flesh) and splitting tendency by different authors from Canada, USA and Hungary.

In Hungary, Simon et al. (2004) observed the cherry fruit quality and cracking ratio from the point of view of cultivars and rootstocks. The cracking tendency was estimated by dipping the fruits, $4 \times 30$ fruits were immersed in water for 4 hours, then cracked fruits were counted. In 1997 and 1998, the cracking ratios after 4 and 24 hours dipping were also calculated. Their results are shown in Table 2. Significant differences were found between the two cultivars in the soluble solids and acid content of the fruit juice and the cracking percentage after dipping. The soluble solids and acid content of the fruit juice were higher in 'Van'. No significant differences occurred in fruit colour. 'Germersdorfi' had significantly higher firmness in comparison with 'Van'.

The cracking percentage after 4 hours' dipping was higher in 'Germersdorfi'. The extraordinarily high cracking percentage $(54.5 \%$, three times higher than 'Germersdorfi') of 'Van' after 24 hours' dipping is worthy of note. This result can be explained by higher sugar content of 'Van' fruits. After a long period ( 24 hours) immersion in water, 'Van' fruits cracked at a higher percentage because their osmotic concentration was significantly higher, and by this way their water uptake through the fruit skin was higher too.

Besides the cultivars, the rootstock also influenced the effect on water uptake of the tree. Of course, the rootstock has less effect on fruit cracking by less amount and slower process of water uptake through the root system than rapid water uptake into fruit directly through the fruit skin.

Simon et al. (2004) showed that there were no differences in the size and firmness of the fruits harvested from trees on the different rootstocks. The soluble solid content of the fruit juice was higher on 'Colt' and 'MxM 97' than on the other rootstocks. It was strange that, after 4-hour dipping, fruits harvested from trees on 'MxM 97' had the highest cracking ratio and 'Colt' had the lowest value when they had almost the same soluble solid content value; however, after 24-hour dipping the opposite trend was observed, 'Colt' had the highest and 'MaxMa 97' the lowest fruit cracking ratio 
Table 1 Fruit parameters and cracking tendency of well known sweet cherry cultivars and varieties grown in Hungary.

(data were collected by the following authors: Andersen et al., 2003, Andersen, 2004; Apostol, 2003; G. Töth, 2001, Nuget, 1999a, 1999b)

\begin{tabular}{|c|c|c|c|c|}
\hline Cultivar & Fruit size & Fruit shape & Firmness & Splitting tendency \\
\hline Bing & large & heart & firm & Susceptible \\
\hline Black gold & moderately large & heart & soft & moderately tolerant \\
\hline Cashmere & moderately large & heart & firm & Susceptible \\
\hline Celeste & large & kidney & firm & Tolerant \\
\hline Chelan & moderately large & heart & firm & moderately susceptible \\
\hline Columbia (Benton) & large & heart & firm & Tolerant \\
\hline Compact Lambert & medium & heart & moderate & moderately susceptible \\
\hline Compact Stella & medium & heart-oval & moderate & moderately susceptible \\
\hline Cristalina & moderately large & heart & firm & tolerant \\
\hline Hartland & moderate large & round-heart & moderate & susceptible \\
\hline Hudson & moderate large & rround-kidney & firm & tolerant \\
\hline Kristin & moderate large & wide heart & firm & tolerant \\
\hline Lapins & large & round & firm & good tolerance \\
\hline Newstar & large & round-kidney & very firm & moderately susceptible \\
\hline Rainer & very large & kidney (blocky) & firm & moderately susceptible \\
\hline Regina & very large & conical round & firm & tolerant \\
\hline Royalton & very large & round-kidney & firm & moderately tolerant \\
\hline Salmo & medium & round & firm & moderately susceptible \\
\hline Sam & moderately large & heart & firm & good tolerance \\
\hline Samba & large & round & firm & good tolerance \\
\hline Sandra Rose & large & round-kidney & moderate & good tolerance \\
\hline Santina & moderately large & oval & moderate & moderately tolerant ("nose" splitting) \\
\hline Simone & large & heart & firm & moderately susceptible \\
\hline Sonata & very large & round & firm & moderately susceptible \\
\hline Sparkle & small-medium & round & moderate & moderately tolerant \\
\hline Star & moderately large & heart & firm & very tolerant \\
\hline Stella & large & heart & moderate & moderately susceptible \\
\hline Sue & medium & round-heart & firm & very tolerant \\
\hline Summit & very large & heart & moderate & tolerant \\
\hline Sunburst & very large & round & moderate & tolerant \\
\hline Sweetheart & medium & round & very firm & moderately susceptible \\
\hline Sylvia & large & heart & very firm & tolerant \\
\hline Tieton & very large & heart & firm & susceptible \\
\hline Ulster & large & heart & firm & moderately tolerant \\
\hline Vega & large & round-kidney & firm & susceptible \\
\hline Van & medium & kidney (blocky) & moderate & moderately tolerant \\
\hline White gold & moderately large & round-heart & moderate & moderately tolerant \\
\hline \multicolumn{5}{|c|}{ Other sweet cherry cultivars grown in Hungary } \\
\hline Aida & large & round & very firm & ND \\
\hline Alex & medium & oblong kidney & firm & ND \\
\hline Bigarreau Burlat & middle & conical round & moderate firm & susceptible \\
\hline Germersdorfi clones & large & round-heart & very firm & susceptible \\
\hline Hedelfinger & medium & oblong heart & moderate firm & moderately susceptible \\
\hline Katalin & large & round & firm & ND \\
\hline Kavics & medium & round & very firm & moderately susceptible \\
\hline Kordia (Attika) & moderate large & heart & firm & moderately tolerant \\
\hline Linda & large & round & firm & ND \\
\hline Margit & large & round & firm & ND \\
\hline Rita & medium & conical round & moderate firm & ND \\
\hline Solymári gömbölyü & moderate large & heart & moderate firm & moderately susceptible \\
\hline Valerij Cskalov & middle & conical round & soft & susceptible \\
\hline Vera & large & round & firm & moderately tolerant \\
\hline
\end{tabular}

ND*data were not found in literature 
Table 2 Fruit quality parameters and cracking ratio of 'Van' and 'Germesdorfi óriàs' sweet cherry cultivars in average of different rootstocks. (Simon et al. 2004)

\begin{tabular}{|c|c|c|c|c|c|c|c|c|c|c|c|c|}
\hline \multirow{2}{*}{$\begin{array}{l}\text { Cultivar } \\
\text { Van }\end{array}$} & \multicolumn{2}{|c|}{$\begin{array}{c}\text { Soluble solid } \\
\text { content }(\%) \\
* *\end{array}$} & \multicolumn{2}{|c|}{$\begin{array}{c}\text { Acid content } \\
(\mathrm{g} / \mathrm{l}) \\
* *\end{array}$} & \multicolumn{2}{|c|}{$\begin{array}{c}\text { Fruit cracking } \\
\text { after } 4 \text { hours }(\%) \\
* *\end{array}$} & \multicolumn{2}{|c|}{$\begin{array}{c}\text { Fruit cracking } \\
\text { after } 24 \text { hours }(\%) \\
* * *\end{array}$} & \multicolumn{2}{|c|}{$\begin{array}{l}\text { Fruit colour } \\
\qquad \begin{array}{l}(1-5) \\
* * *\end{array}\end{array}$} & \multicolumn{2}{|c|}{$\begin{array}{c}\text { Fruit firmness } \\
\left(\mathrm{N} / \mathrm{cm}^{2}\right) \\
* * *\end{array}$} \\
\hline & 18.20 & b & 1.44 & b & 2.13 & $\mathrm{a}$ & 54.52 & b & 4.65 & a & 2.62 & a \\
\hline $\begin{array}{l}\text { Germersdorfi } \\
\text { óriás }\end{array}$ & 17.58 & a & 1.13 & a & 7.11 & b & 17.48 & $\mathrm{a}$ & 4.95 & a & 3.14 & b \\
\hline
\end{tabular}

* average of 6 years (1993-98)

** average of 4 years (1995-98)

*** average of 2 years (1997-98)

Table 3 Fruit quality parameters and cracking ratio of four different cherry rootstock in the average of grown cultivars. (Simon et al. 2004)

\begin{tabular}{|c|c|c|c|c|c|c|c|c|c|c|c|c|}
\hline \multirow{2}{*}{$\begin{array}{l}\text { Rootstocks } \\
\text { SL64 }\end{array}$} & \multicolumn{2}{|c|}{$\begin{array}{c}\text { Soluble solid } \\
\text { content }(\%) \\
* *\end{array}$} & \multicolumn{2}{|c|}{$\begin{array}{l}\text { Acid content } \\
\qquad \begin{array}{c}(\mathrm{g} / \mathrm{l}) \\
* *\end{array}\end{array}$} & \multicolumn{2}{|c|}{$\begin{array}{l}\text { Fruit cracking } \\
\text { after } 4 \text { hours }(\%) \\
\qquad *\end{array}$} & \multicolumn{2}{|c|}{$\begin{array}{c}\text { Fruit cracking } \\
\text { after } 24 \text { hours }(\%) \\
* * *\end{array}$} & \multicolumn{2}{|c|}{$\begin{array}{l}\text { Fruit colour } \\
\qquad \begin{array}{c}(1-5) \\
* * *\end{array}\end{array}$} & \multicolumn{2}{|c|}{$\begin{array}{l}\text { Fruit firmness } \\
\qquad \begin{array}{c}\left(\mathrm{N} / \mathrm{cm}^{2}\right) \\
* * *\end{array}\end{array}$} \\
\hline & 17.67 & a & 1.17 & $\mathrm{a}$ & 4.18 & $a b$ & 37.66 & $a b$ & 4.80 & a & 2.62 & a \\
\hline Colt & 18.29 & b & 1.39 & $\mathrm{a}$ & 2.85 & a & 40.85 & $\mathrm{~b}$ & 4.72 & a & 2.82 & $\mathrm{a}$ \\
\hline MxM 97 & 18.02 & $\mathrm{~b}$ & 1.36 & a & 6.30 & $\mathrm{~b}$ & 27.81 & a & 4.84 & a & 2.96 & a \\
\hline MxM 14 & 17.60 & a & 1.23 & a & 5.20 & $a b$ & 37.68 & $a b$ & 4.82 & a & 2.78 & a \\
\hline
\end{tabular}

- average of 6 years (1993-98)

$*$ average of 4 years (1995-98)

$* * *$ average of 2 years (1997-98)

(Table 3). To get more clear correlations between cultivars, rootstock and cracking, more detailed studies on these data should be carried out in the future.

\section{Rain cover protection:}

There are many publications on the usage and experiences of several rain protection cover systems (Meli, 1982; Gillespie, 1988; Opperman, 1988; Pennel \& Webster, 1996; Meland \& Skjervheim, 1998; Borve \& Meland, 1998; Balmer, 1998 etc). Trials with application of cover materials began first in Switzerland where rain in the harvest time frequently induced fruit splitting and crop loss (Meli, 1982). Stout posts with $6.0-6.5 \mathrm{~m}$ height were erected within the tree rows on top of which steel arcs up to $6.0 \mathrm{~m}$ width were attached. After this, similar trials started in Belgium, the Netherlands, United Kingdom, and New Zealand. In these early cover trials, almost the whole tree (the top and side of the tree) was covered by $0.2 \mathrm{~mm}$ plastic material. By the experiences of researchers and cherry growers at least three weeks before harvest, often when about the time when cherries start to change colour and become sensitive to rain damage, needs to start covering the trees. Despite of high temperature and higher humidity under the cover system (more favourable conditions for disease infection), they operated more economically than the uncovered orchard. Picking efficiency, yield, fruit size and the quality of harvested fruits were improved greatly; it was about 20-60\% premium in years of persistent or heavy rainfall at harvest compared to uncovered orchards.

Other researchers found some disadvantageous factors of the first rain cover systems: the temperature under the covers may become too hot causing scorching, and damages on leaves, shoots and the whole tree; by the higher humidity the risk of disease infection increased; fruits were harvested 1-5 days later. To save the orchard of these problems, trees were covered only on the top and permit free airflow into the sides of the rows.

Research started in the USA to develop special for orchard covering, which is impermeable to rain but allows some gas exchange (Opperman, 1988)

In Norway, Borve \& Meland established cherry trial orchard to compare the effectiveness of different rain protecting cover systems. The rain cover constructions in Norway have developed from covering only single trees (umbrella) to covering whole tree rows. Borve \& Meland (1998b) found the trees tested with three covering methods increased the portion of marketable yield by reducing the number of cracked and rotten cherry fruits (Table 4, Borve \& Meland, 1998b).

In Norway, under rainy weather conditions at cherry harvest time two different, and really effective rain cover systems - one wire system and three wire system - were developed for protection against the rain induced fruit cracking of sweet cherries. They seem to be the most applicable in intensive cherry orchards.

For both systems, some common demands are essential in order to get a stable and long lasting system. The main frame for the cherry orchard cover consists of wooden poles supporting an overhead wire system running dowri each tree row. Inside the rows, wooden $5 \mathrm{~m}$ tall poles of $10 \mathrm{~cm}$ in diameter are spaced about $12 \mathrm{~m}$ apart. In order to stabilise the poles, they are set 1-2 $\mathrm{m}$ in the ground by machinery or hand. This provides an above ground height of maximum $4 \mathrm{~m}$. At 
Table 4 The effects of different covering systems for rain protection on cracked fruits, rotten fruits, fruits with other culls and marketable fruits of 'Van' sweet cherries during two growing seasons. (by Børve \& Meland. 1998 in Norway at Ullesvang Research Centre)

\begin{tabular}{|l|c|c|c|c|c|c|c|c|}
\hline \multirow{2}{*}{ Covering system } & \multicolumn{2}{|c|}{ Cracked fruits, \% } & \multicolumn{2}{|c|}{ Rotten fruits, \% } & \multicolumn{2}{c|}{ Fruits with other culls, \% } & \multicolumn{2}{c|}{ Marketable fruits, \% } \\
\cline { 2 - 10 } & 1994 & 1995 & 1994 & 1995 & 1994 & 1995 & 1994 & 1995 \\
\hline Uncovered & 11.7 & 17.4 & 47.8 & 9.8 & 1.8 & 1.3 & 38.7 & 71.1 \\
\hline Permanent coved & 3.0 & 1.3 & 7.3 & 1.2 & 2.8 & 1.8 & 86.9 & 95.7 \\
\hline Raincovered & 2.3 & 1.8 & 8.3 & 1.2 & 5.0 & 2.4 & 84.7 & 94.7 \\
\hline Umbrella covered & 2.0 & 0.7 & 6.8 & 0.8 & 3.2 & 2.7 & 87.7 & 95.8 \\
\hline LSD $(\mathrm{P}=5 \%)$ & 4.9 & 2.9 & 9.3 & 3.4 & NS & NS & 10.7 & 5.0 \\
\hline
\end{tabular}

NS = difference is not significant

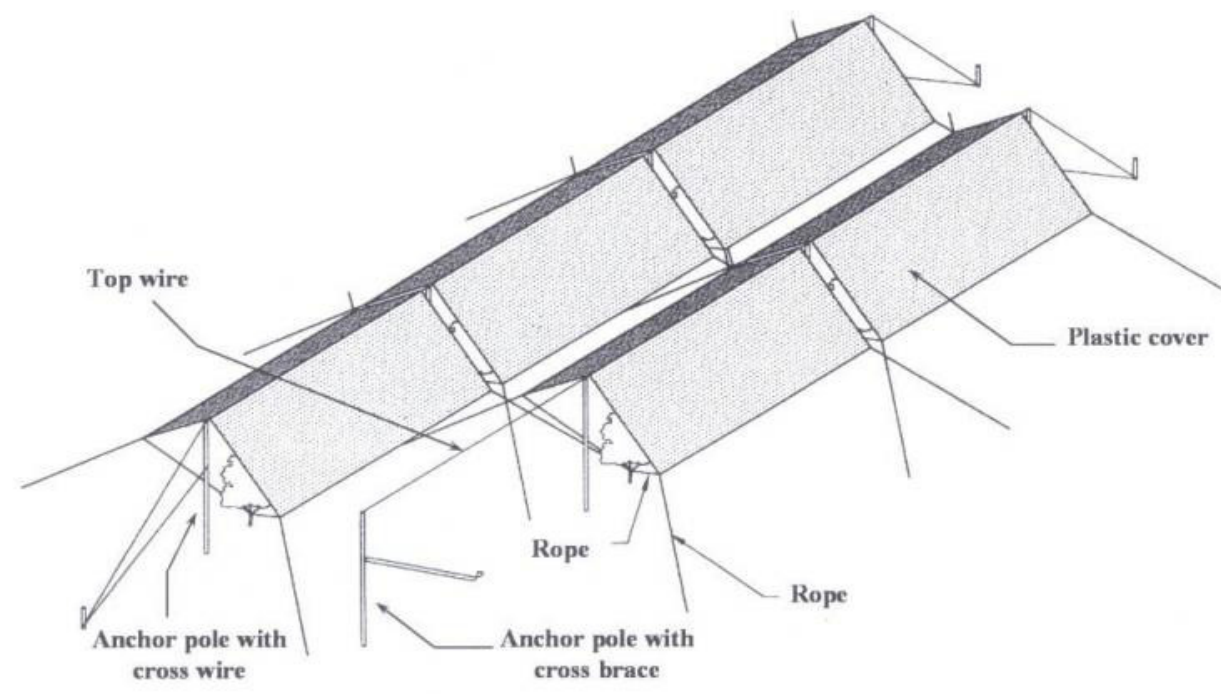

Figure 2 Rain covers system for protection of rain damage of sweet cherries. One wire system. (by Borve \& Meland, 1998)

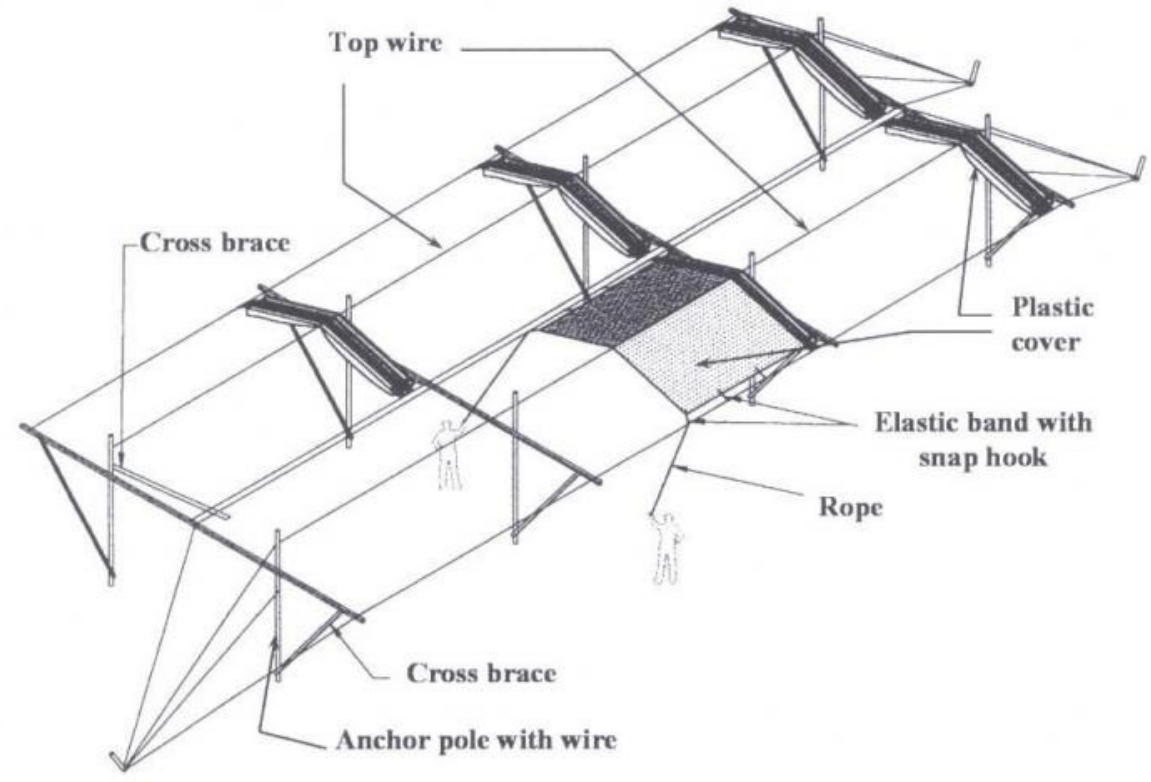

Figure 3 Rain covers system for protection of rain damage of sweet cherries. Three wire system. (by Borve \& Meland, 1998a) the ends of the tree rows, heavier poles of $14 \mathrm{~cm}$ diameter are recommended (Selberg \& Skjervheim, 1992; Selberg et al., 1995; Skjervheim et al., 1997

Based on my personal experience in Geneva at NYSAES, if the orchard is located in a windy site then heavier and chargeable poles have to be used at the ends of rows, otherwise in heavy storms they can get broken. In Geneva, NY-USA in 2002 in a windy storm the anchor poles were broken and they were replaced with thicker poles (Figure 5).

Main structure of one wire system (Borve \& Meland, 1998; Figure 2):

One high tensile wire is connected on the top of the poles and anchored in the ground at both ends. The overhead cover is supported by this top wire. The width of cover sheets depends on the tree row spacing. The cover sheets are tied with ropes to the neighbor rows on each side. One part of tying ropes should be flexible to resist the wind power. This simple cover system is permanent in ripening time. A tractor can not pass in the alleyways when the cherry trees are covered.

Main structure of the three wire system (Borve \& Meland, 1998; Figure 3):

The supporting framework is entirely built of wood. The poles are connected to each other with transverse wood work, $10 \mathrm{~cm} \times 10 \mathrm{~cm}$ at the anchor poles and $5 \mathrm{~cm} \times 10 \mathrm{~cm}$ in the rows. The overhead curtains slide back and forth to open and close on three wires down the row. The top 


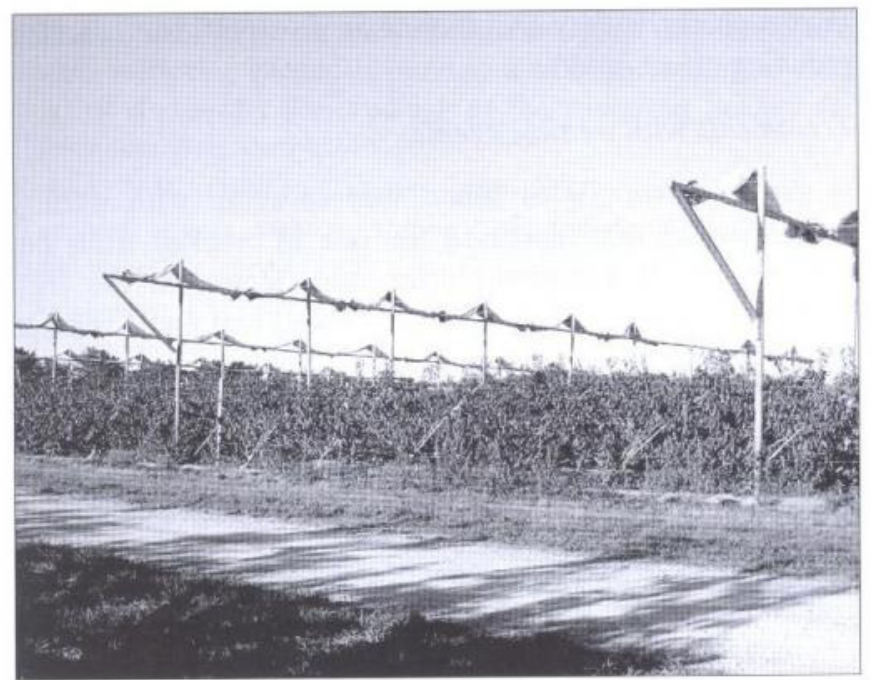

Figure 4 Three wires rain cover protection in the USA, in Geneva at NYSAES (Picture: Simon, G., 2002)

wire is positioned about $4 \mathrm{~m}$ above the ground and maximum $0.5 \mathrm{~m}$ higher than the side wires. The polyethylene cover is therefore gabled around the centre axis. The horizontal distance between the two side wires is row distance minus $0.1 \mathrm{~m}$. A maximum tree height of about $3.5 \mathrm{~m}$ in the beginning of the season is appropriate. Cross laminated or woven polyethylene sheets are used as curtains. It is important to find covers which combine strength, low weight and acceptable price. The curtain length is similar to the pole spacing in the row. When sheets with eyelets are used, the width should be the row spacing minus $0.5 \mathrm{~m}$. Recommended eyelets distance along the sheet side is $1 \mathrm{~m}$, but at each end half that distance is recommended in order to strengthen and secure the cover. Through each eyelet an elastic rubber band is treaded and equipped with a snap hook. These hooks are connected to the side wires and slide back and fourth on these wires when the curtain operates.

In 1999, a replicated cherry systems trail was established at Geneva, NY with 3 cultivars (Hedelfingen, Lapins and Sweetheart) and 3 rootstocks (Gisela unknown, Gisela 6 and MxM.2). The purpose of this trial is to compare high-density training systems (Modified Central Leader, Spanish Bush, Vogel Slender Spindle; Marchant Trellis and Zahn Vertical Axis) that utilize precocious rootstocks and new pruning and training strategies. Two replication blocks were established one of them was uncovered and the other covered with rain exclusion shelters (three wire rain-cover system) (Robinson et al. 2002). The trial orchard is shown in Figure 4.

\section{Spraying of cherry fruits with minerals or other chemicals:}

There are many ports in the literature suggesting that sprays of mineral salts, fungicides and other chemicals reduce cherry cracking. Any compounds with positive effect in reducing fruit cherry fruit cracking maybe expected to have at least one of the following characteristics (Christensen, 1996):

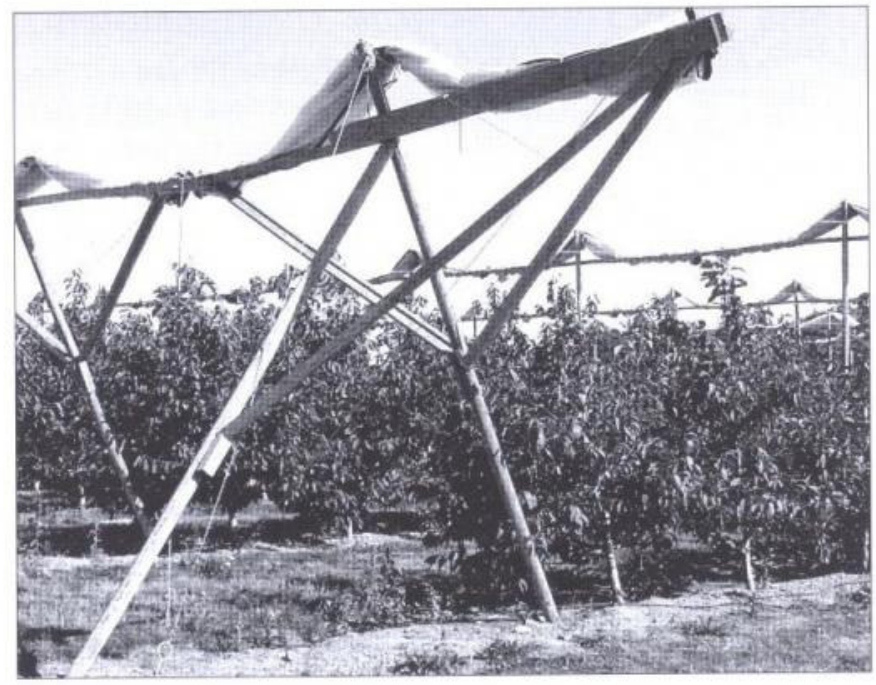

Figure 5 Anchor pole of three wires rain cover protection in the USA, in Geneva at NYSAES (Picture: Simon. G., 2002)

- Cause to delay or reduces the amount of water uptake into the fruit;

- Increases transpiration of free water from the fruits surface;

- Improves the fruit skin (strength, plasticity or elasticity, cuticular properties)

Calcium sprayings reduce the cracking tendency of cracking:

Physiological background: Among the macro elements the calcium is taken up in the highest amount by fruit trees, but only a small amount of the calcium is transported into the fruits. Calcium together with potassium play a very important physiological role in controlling of plasma colloids and the strength of the cell walls (Papp, 1997). Faust (1989) noted that the calcium is the most important element considering the fruit quality and storage life. The most of physiological disease and storage disorders of fruits are correlated positively with calcium deficit.

Bangert (1968) observed 8 sweet cherry varieties and found positive correlation between the natural calcium content of cherry fruit and their cracking tendency. Glenn \& Poovaiah (1989) showed that calcium treatments increase the strength and elasticity of cell walls of the fruit skin.

To take the positive physiological advantages of calcium shown above, presently calcium treatment in sweet cherry orchards is suggested by the followings:

- calcium directly decreases the amount of water taken up into the fruit through the skin and by this way cracking tendency is decreased;

- in a long-term effect calcium has positive effect on tissue structure, strength and elasticity of the fruit skin; and it has also positive effect on storage and shelf life too.

Many researchers attempted to reduce the cherry fruit cracking by calcium sprayings (Bullock, (1952); Ono et al., 
(1954); Ackley, (1956), Bangerth, (1968); Christensen, (1972c, 1976); Callan, (1986); Lang et al. (1998)).

The researchers who used the calcium sprayings in field trials to reduce the cherry fruit cracking noted the followings:

- Calcium chloride $\left(\mathrm{CaCl}_{2}\right)$ is showing good potential as a treatment for reducing rain cracking of cherries.

- Calcium chloride solution, when applied in response to rainfall, reduced the level of cracking on cherries.

- The effectiveness of the treatment varied between varieties, orchards and seasons. This variation is suggested to be partly due to different rainfall patterns between orchards and seasons. Some fine-tuning is required to match the environmental triggers to the application of $\mathrm{CaCl}_{2}$ (i.e. to know in advance the level of rain required before the $\mathrm{CaCl}_{2}$ is applied).

- The $\mathrm{CaCl}_{2}$ treatment does not appear to affect maturity, fruit size or storage of cherries.

- In some orchards the major problem was that residuals are left on fruits by the quite concentrated sprays used.

Based on the results of trials with calcium chloride and applied growing technologies it seems that a $0.35-1.0 \%$ calcium chloride solution is effective in cherry orchards to reduce the cracking tendency. It is possible to use traditional plant protection equipments for spaying with calcium solution before and during rain. There are some examples with fixed overhead sprinkling spraying with calcium solution during the rain.

Some other calcium salts can be used for spraying in appropriate concentration to reduce the fruit cracking such as calcium nitrate, calcium hydroxide.

Spraying with aluminium, copper,and other metallic salts, boron:

Bullock (1952) had studied different metallic salts and their effect on reducing fruit cracking. He found that aluminium salts had a stronger effect on reducing fruit cracking than calcium. Aluminium phosphate $\left(\mathrm{Al}_{3}\left(\mathrm{PO}_{4}\right)_{2}\right)$ solution was sprayed of $0.01-0.1 \mathrm{M}$ concentration 8-18 before the harvest. Some other studies showed similar results. The spraying with aluminium salts did not spread in commercial orchards because of visible deposits left on the fruits and the risk of spray's scorching.

Copper salts are used for spraying in horticulture for a long time such as "Bordeaux mixture". Spraying with copper sulphate $\left(\mathrm{CuSO}_{4}\right)$ solution in $0.1 \%$ concentration decreased the fruit cracking.

In the case of spraying with other metallic salts (iron chloride, iron nitrate, magnesium, zinc, manganese and iron sulphate) there was no significant effect on reducing fruit cracking (Bullock, 1952; Christensen, 1972c).

Powers \& Bollen (1947) showed that immersing in borax solution of $0.25 \%$ concentration reduced fruit cracking by $50 \%$. Knoppien (1949) noted that spraying with borax solution in $0.5-1.0 \%$ concentration was effective in the case of one cherry variety and there was no significant cracking reducing effect on others.

\section{Treatments with wetting agents:}

Christensen (1976) found that spraying with wetting agents before rain increased the rate of cracked fruits but wetting agents treatment after rain decreased the fruit cracking tendency. Several trials showed that fruits sprayed with wetting agents before the rain dried up within 15-20 minutes after rain, but untreated fruits were still wet after 1.52 hours later.

\section{Final conclusion:}

The best method to reducing the risk of cherry fruit cracking is to choose the most resistant cultivars and to minimize risk of growing several varieties with different ripening time in the same orchard. In some countries with very rainy climate conditions, the application of rain protecting covers is the best solution to have high value marketable fresh cherries. In other countries with better climate conditions, spraying in harvest time with several mineral solutions (calcium chloride for spraying in solution is wide spread) can reduce the ratio of cracked fruit in a sufficiently effective way.

\section{References}

Ackley, W.B. (1956): Fruit cracking of sweet cherries. Washington State University Progress in Agriculture and Home Economics Research, Progress Report No. 9.

Andrsen, R.L., Lang, G. \& Nuget, J. (2003): Fresh Market Sweet Cherry Varieties for Eastern North America. New York Fruit Quarterly. 11. (2): 11-14.

Andrsen, R.L. (2002): Personal communication at Cherry Fruit Day in Geneva - NYSAES.

Andrsen, R.L. (2004): WhiteGold ${ }^{\otimes}$ : A New White Fleshed Sweet Cherry From Geneva. New York Fruit Quarterly. (12) 2: 1.

Apostol, J. (2003): Cseresznye- és meggynemesités, a fontosabb fajták leirása. In Hrotkó, K. (szerk): Cseresznye és meggy. Mezögazda Kiadó, Budapest, 37-95.

Balmer, M. (1998): Preliminary Result on Planting Densities and Rain Covering for Sweet Cherry on Dwarfing Rootstocks. Acta Horticulturea 468: 433-440.

Bangerth, F. (1968): Zur ursache des Platzen von Kirschenfrüchten. In ISHS Symposiumon Cherries. Istitut für Obstbau de Universität Bonn, Germany, 198-201.

Belmans, K., Keulemans, J. \& Bronchart, R. (1989): Sensibilitée variétale á l'éclatement chez les cerisesdouces. Revue de l'Agriculture (42): 155-162.

Belmans, K., Keulemans, J., Debarsy, T. \& Bronchart, R. (1990): Influence of sweet cherry epidermal characters on susceptibility to cracking Proceedings of the International Horticulture Congress XXIII. 637.

Børve, J. \& Meland, M. (1998a): Rain cover protection against cracking for cherry orchards. Acta Horticulturae 468: 441-447.

Børve, J. \& Meland, M. (1998b): Rain cover protection against cracking of cherries. I. The effects on marketable yield. Acta Horticulturea 468: 449-454. 
Bullock, R.M. (1952): A study of some inorganic compounds and growth promoting chemicals in relation to fruit cracking of Bing cherries at maturity. Proceedings of the American Society for Horticultural Science 59: 243-253.

Callan, N.W. (1986): Calcium hydroxide reduces splitting of 'Lambert' sweet cherry. Journal of American Society for Horticultural Science 111 (2): 173-175.

Christensen, J.V. (1972a): Cracking in Cherries III. Determination of cracking susceptibility. Acta Agriculturae Scandinavica 22: 128-136.

Christensen, J.V. (1972b): Cracking in Cherries IV. Physiological studies of the mechanisms of cracking. Acta Agriculturae Scandinavica 22: 153-162.

Christensen, J.V. (1972c): Revnedannelse i kirsebaer V. Nogle salte og kemikaliers virkning pa revnetilbojeligheden. (Cracking in cherries $\mathrm{V}$. The influence of some salt and chemicals on cracking.) Frukt og Baer Oslo 37-47.

Christensen, J.V. (1975): Cracking in Cherries VII. Cracking susceptibility in relation to fruit size and firmness. Acta Agriculturae Scandinavica 25: 301-312

Christensen, J.V. (1976): Revnedannelse i kirsebaer. (Cracking in Cherries.) Danish Journal of Plant and Soil Science 80: 289-324.

Christensen, J.V. (1996): Rain-induced fruit cracking of sweet cherries: Its causes and prevention. In A.D. Webster and N.E. Looney (eds) Cherries: Crop Physiology, Production and Uses. Cab International, UK. 297-327.

Faust, M. (1989): Physiology of temperate zone fruit trees. John Wiley and Sons Inc., New York, Singapore.

G. Tóth, M. (2001): Cseresznye. In G. Tóth, M. (szerk) Gyümölcsészet. PRIMOM Sz-Sz-B. Megyei Vállalkozásélénkitô Alapitvány Vállalkozói Központ, Nyiregyháza, 68-288.

Gilepire, J.R. (1988): An evaluation of cherry production in New Zealand. Acta Horticulturae 223: 93-100.

Glenn, G.M. \& Poovaiah, B.W. (1989): Cuticular properties and postharvest calcium application influence cracking of sweet cherries. Journal of American Society for Horticultural Science 114 (5): 781-788.

Holb, I.J. (2003): The brown rot fungi of fruit crops (Monilinia spp.) I. Important features of their biology (Review). Int. J. Hortic. Sci. $9(3-4): 23-36$.

Holb, I., Veisz, J. Abonyi, F. (2005): A meggy és cseresznye komplex ökológiai növényvédelmi technológiảja. pp. 168-171. In: Holb, I. (szerk.) A gyümölcsösök és a szölö ökológiai növényvédelme. Mezögazda Kiadó, Budapest, 341 pp.

Kertesz, Z.I. \& Nebel, B.R. (1935): Observations on the cracking of cherries. Plant Physiology 10: 763-772.

Knoppien, P. (1949): Het Scheuren van kersen. Mededelingen van Directeaur van Tuinabngewassen 12: 77-78.

Lang, G.A., Guimond, C.M., Floree, J.M., Facteau, T.J., Azarenko, A., Kappel, F. \& Southwick, S. (1998): Performance of calcium/sprinkler-based cherry cracking prevention strategies. Acta Horticulturae 468: 649-656.

Meland, M. \& Skjervheim, K. (1998): Rain cover protection against cracking for sweet cherry orchards. Acta Horticulturae 486: 441-448.

Meli, T. (1982): Abdecken von Susskirschen-hecken mit Polyathylenfolien: I. Voraus-setzungen fur das Abdecken. II. Technik des Abdeckens. III. Betriebs- und arbeit- swirtschaftliche Aspekte (Covering sweet cherry hedges with polyethylene. I. Prerequisites of covering. II. Techniques of covering. III. Plantation and labour economy aspects.) Scweizerische Zeitschrift für Obstund Weinbau $110(25,26,27) 761-768,778-794,812-821$.

Nuget, J.E. (1999): Comments on light sweet cherry cultivars. Web site of Northwest Michigan Horticultural Research Station, URL (2006.01.20.): http://www.maes.msu.edu/nwmihort/ Ltswtchr.html

Opperman, D. (1988): Cherry umbrella tried protection against frost, wind and rain. Good fruit Grower 39: 26-30.

Papp, J. (1997): A tápelemek és szerepük. in Integrált gyümölcstermesztés. (szerk. Soltész M.) Mezögazda Kiadỏ, Budapest, 1997.

Pennel, D. \& Webster, A.D. (1996): Protection of fruit from Damage. in ed: Webster, S.D. \& Looney, N.E. (1996): Cherries: Crop Physiology, Production and Uses. Cab International, UK.

Powers, W.L. \& Bollen, W.B. (1947): Controll of cracking of fruit by rain. Science 105: 334-335.

Robinson, T.L., Andersen, R.L. \& Hoying, S. (2002): Cherry report of "High-Density Planting Systems for Sweet Cherries in the Northeast" project Manuscript.

Sawada, E. (1931): Studies on the Cracking of cherries. Agriculture and Horticulture 6: 864-892.

Sekse, L. (1987): Fruit cracking in Norwegian grown sweet cherries. Acta Agriculturae Scandinavica 37: 325-328.

Seldberg, A. \& Skjervheim, K. (1992): Dekkesystem mot sprekking av søtkirsebx. (Covering system against cracking of sweet cherries). Faginfo nr.15 1992. Statens Fagteneste for Landbruket. $16 \mathrm{pp}$.

Seldberg, A., Birkeland, H.M. \& Meland, M. (1997): Dekkesystem for morellplantingar. Bygge-og bruksrettleiing. (Covering system against cracking of sweet cherries. Construction guide). Grønn Forsking 22/97. Norwegian Crop Research Institute. $42 \mathrm{pp}$.

Seldberg, A., Skjervheim, K., Meland, M., Ulgenes, J. \& Hovland, O. (1995): Dekkesystem mot sprekking av søtkirsebæ. Byggjerettleiing. (Covering system against cracking of sweet cherries. Construction guide). Faginfo nr.7 1995. Infosenteret Forskingsparken i Ås. 28 pp.

Simon, G. (2003): Az ültetvények védelme az esö és a madarak által okozott károk ellen. In Hrotkó, K. (szerk): Cseresnye és meggy. Mezögazda Kiadó, Budapest, 338-348.

Simon, G., Hrotkó, K. \& Magyar, L. (2004): Fruit quality of sweet cherry cultivars grafted on four different rootstocks. Acta Horticulturae 658: (1): 365-370.

Tucker, R. (1934): A varietal study of the susceptibility of sweet cherries to cracking. University of Idaho Agriculture Experimental Station Bulletin 211: 1-15.

Uriu, K., Hansen, C.J. \& Smith, J.J. (1962): The cracking of prunes in relation to irrigation. Proceedings of the American Society for Horticultural Science 80: 211-219.

Verner, L, \& Blodgett, E.C. (1931): Physiological studies of the cracking of sweet cherries. University of Idaho Agriculture Experimental Station Bulletin No. 184

Verner, L. (1937): Reduction of cracking in sweet cherries following the use of calcium sprays. Proceedings of the American Society for Horticultural Science 36: 271-274.

Way, R.D. (1967): Cherry varieties for New York State. Cornell Extension Bulletin 1197. New York State College of Agriculture.

Zielinski, B.Q. (1964): Resistance of sweet cherry varieties to fruit cracking in relation to fruit and pit size and fruit colour. Proceedings of the American Society for Horticultural Science 84: $98-102$. 